\title{
Macropolitics and Microperceptions: Is There a Possible Market Answer to Water Woes in Ambovombe-Androy, Madagascar?
}

\author{
Richard R. Marcus \\ International Studies Program, California State University, Long Beach, USA. \\ Email: richard.marcus@csulb.edu
}

Received March 21 $1^{\text {st }}$ 2102; revised August $9^{\text {th }}$, 2012; accepted September $14^{\text {th }}, 2012$

\begin{abstract}
In Ambovombe-Androy water is scarce, time-consuming to obtain, and expense. Nonetheless, there is little study into the complexity of popular perception of costs for services in Madagascar. This paper addresses this gap. It is based on a district-wide household survey, focus groups, and interviews. It looks at the wide variation in pricing expectations across a number of intra-community demographic groups and economic classes before considering the user perceptions of water markets themselves as determinants of their willingness to pay. It concludes by isolating the determinants under which and places in which the new macro-level strategies are likely to be accepted, and work, at the community level in Ambovombe-Androy.
\end{abstract}

Keywords: Madagascar; Water Policy; Water Management; Ambovombe

\section{Introduction}

Ambovombe-Androy is a semi-arid district in Madagascar's extreme south ${ }^{1}$. The relatively homogenous population survives on a combination of small-holder agriculture and pastoral activities. Obtaining water for basic human needs is overwhelmingly the largest concern of the populace. As a hydrologically closed basin with a rapidly growing population water is scarce, expensive, and time-consuming to obtain. The district thus serves as a tremendous test for new state and donor funded initiatives to increase the percentage of the population with safe water access from 35 percent in 2006 to 65 percent in 2012. Water is integrated into broader decentralizing governance and development strategies. As such, the government has been very articulate on the mechanisms for augmenting water access: build more community

\footnotetext{
${ }^{1}$ In September 2004 President Marc Ravalomanana passed, by decree, a change in local government structure that removed power from the district level and vested it in a newly created region level. There are 22 regions in Madagascar and leadership is appointed by the executive. The change to the region was ratified in a constitutional referendum on 4 April 2007. Changes in power structure in Ambovombe-Androy did not take hold until 2006 when this study was well under way using district delimiters. Thus this study uses the old district boundaries not the region boundaries. The region, Androy, is not hydrologically closed but there also is no river flow. It would be reasonable to expect, therefore, that the challenges to the 17 communes within Ambovombe district would be the same but that perhaps some of the other communes in the region might have different challenges.
}

wells, set up community-managed integrated water systems, and promote private-public partnerships. What is less well articulated, but nonetheless clear, is how this is to be paid for. As put in a recent World Bank water project document [1], there will be "full cost recovery and acceptable O \& M" or even, in another recent World Bank water project document even full cost recovery and $100 \%$ $\mathrm{O} \& \mathrm{M}$. The presumption is that user fees can drive a sustainable water market. While there is some contingent valuation modeling in Madagascar, from which conclusions are extrapolated to the Androy region for policy purposes, there is little study into the contextual factors that drive local willingness-to-pay at the local level in Ambovombe. The gap in contextual knowledge is particularly acute in Southern Madagascar for when it comes to basic needs there tends to be high variation. For instance, a recent JICA (Japanese International Cooperation Agency) study of user-fee based health care services in rural Madagascar found that the conditions under which user fees of health care services will improve health service effectiveness, efficiency and equity are difficult to determine. Based on a robust literature, higher levels of intra-community variation leads to more complex determinants of willingness. It thus would seem that willingness-to-pay needs to be as much a social measure as an economic one. This paper is such an effort. It is based on a district-wide household survey $(n=521)$, focus groups, and interviews by the author in 2002, 2004, 2005, 2006, 
and 2010. It takes as its starting point the survey finding that 70 percent of district residents are willing to pay on average an extraordinary 101 Ariary per bucket (US\$ 3.37 per $\mathrm{cm}$ ) if it ensures year-round resource availability. It goes on to model the wide variation in that willingness across a number of intra-community demographic groups and economic classes, and the perceptions of that willingness-to-pay, before considering the user perceptions of water markets themselves as determinants of their willingness. This paper concludes by isolating the determinants under which and places in which the new macrolevel strategies are likely to be accepted, and work, at the community level in Ambovombe-Androy.

\section{Global Currents in Local Water Management: Integrated Water Resource Management}

\subsection{Overview}

From the Industrial Revolution to the 1980s water was thought of as a resource to capture for human needs. If we can just dam it, divert it, move it, and swallow it, then we can not only slake our thirst but increase our agricultural productivity and industrial capacity, while moving our barges with increasing efficiency. This "hard path" [2] reified engineering as the answer to a natural resource need. The Green Revolution of the 1960s led, with some lag time, to recognition that engineering, and particularly dams, lead to grave environmental consequences. The knee-jerk reaction was to engineer around the impact: dams were fitted with "fish ladders" to ensure endangered species could make it to spawning grounds, water storage facilities allowed for the harnessing of high season flows to be used in place of streaming surface water in the dry months. A realization followed. Water is a finite resource. As such it is subject to the laws of resource maximization. We need to manage it with the utmost efficiency. It is possible to create utilitarian models to ensure that each drop is accounted for. It is further possible to create incentives for improved resource use. Economists spent much of the 1990s discussing how we value, evaluate, and create a valuation of water. Water became an economic good. As with any good we want to maximize, we moved away from constant water pricing. Block or scaled pricing became popular. Higher demand in the face of diminished quantity drives water prices higher while more efficient use and expanded supply reduces the economic burden.

The focus on management of water resources came at a time when natural resource approaches opened its eyes to the power of scale inputs. The focus of scholars and practitioners alike was to find ways of integrated stakeholders across scales. In theory this is an outgrowth of community-based natural resource management (CBNRM). CBNRM can be viewed as either a part of or a reaction to the neoliberal economic approaches which reclaimed popularity in the early 1990s [3]. Neoliberal CBNRM approaches focused on the economic good that can be gained from the market implications of local management. Challenges to neoliberalism from CBNRM looked to contextualize economic difference. Far from new, the basis for neoliberal versions of CBNRM can be traced to Lockean notions of private property. More than a century ago scholars debated the right of Scottish communities to govern natural resources independent of England [4]. The most recent incarnation of community-based natural resource management is thus more about process (how to achieve it) than it is about theoretical invention. Yet, until recently the resource thought of was either land or forest. The discussion about local water governance circled predominantly around irrigation districts and other consumptive uses as opposed to cross-level governance of an integral supply. Thus the concept of Integrated Water Resource Management (IWRM) began to be discussed in the 1960s. However, its early incarnations considered only organizational arrangements, not matters of scale [5]. Water wasn't considered a local—or localizable—good until we began thinking about it as commodifiable as two decades ago.

The Fourth World Water Forum (in Mexico City, March 2006) was entitled "Local Actions for a Global Challenge," yet it was filled by a growing chorus of voices reflecting a concern that IWRM creates particularized problems for community level action [6]. Perhaps scholars calling for a more sophisticated middle lens for viewing state (and international) action and localized governance needs to be achieved. In her keynote address to that body, Katherine Sierra, World Bank vice President for Infrastructure, articulated the questions the epistemic community has been working with: How can water resources be managed and developed to promote growth and alleviate poverty in a responsible manner? And how can this be done so that environmental resources are not destroyed, and all people can reap the benefits?” Her answer was a common theme in the forum. We must accept the bases of the Dublin Principles [7]:

1) Fresh water is a finite and vulnerable resource, essential to sustain life, development and the environment;

2) Water development and management should be based on a participatory approach, involving users, planners and policy-makers at all levels;

3) Women play a central part in the provision, management and safeguarding of water;

4) Water has an economic value in all its competing uses and should be recognized as an economic good.

The last of these is central to the thesis of this paper so 
it is worth quoting further:

"Within this principle, it is vital to recognize first the basic right of all human beings to have access to clean water and sanitation at an affordable price. Past failure to recognize the economic value of water has led to wasteful and environmentally damaging uses of the resource. Managing water as an economic good is an important way of achieving efficient and equitable use, and of encouraging conservation and protection of water resources.”

From this, Sierra and Forum declaration follow, markets are a management tool, not a good in themselves. Thus the state has a role in regulating the market and creating opportunities even while markets and communities have roles in ensuring a price that can lead to sustainable infrastructure and regularized water delivery. In the context of Southern Madagascar the planners and policymakers are at the national level_primarily within the Ministry of Energy (formerly Ministry of Energy and Mines) which not only guides policy but overseas the only government source in the region, the AES (Alimentation en Eau dans le Sud). Local participation is predominantly comprised of private borehole owners, though there are a small number of community wells, boreholes, and rainwater catchment systems funded by international donors and built by non-government organizations. Price is a function of two sources of supply: AES water and private boreholes. AES water is extremely limited. There are no pipelines going into Ambovombe district, indeed no permanent water source at all. There are a small number of AES boreholes but these are limited to Ambovombe town, depleted in the dry season, and commonly saline in the wet season. AES water trucks ferry water from Mandrare River (neighboring Amboasary district; see Figure 1). However, this system, founded by JICA in the early 1990s, has decayed. By 2010 a maximum of $36 \mathrm{~cm}$ per day could be transported by truck and the distribution of this water is corrupted by the personal influence of large landholders and water brokers [8]. The constraint on supply ensures erratic prices and predatory private markets. In the rainy season a bucket of water may cost 50 ariary (US\$ 0.03 ) per 15 liter bucket (US\$ $2 / \mathrm{cm})$. In the dry season predatory water markets can drive prices upwards of 500 ariary (US\$ 0.28) per bucket (US\$ $18.66 / \mathrm{cm}$ ), just slightly over the average daily

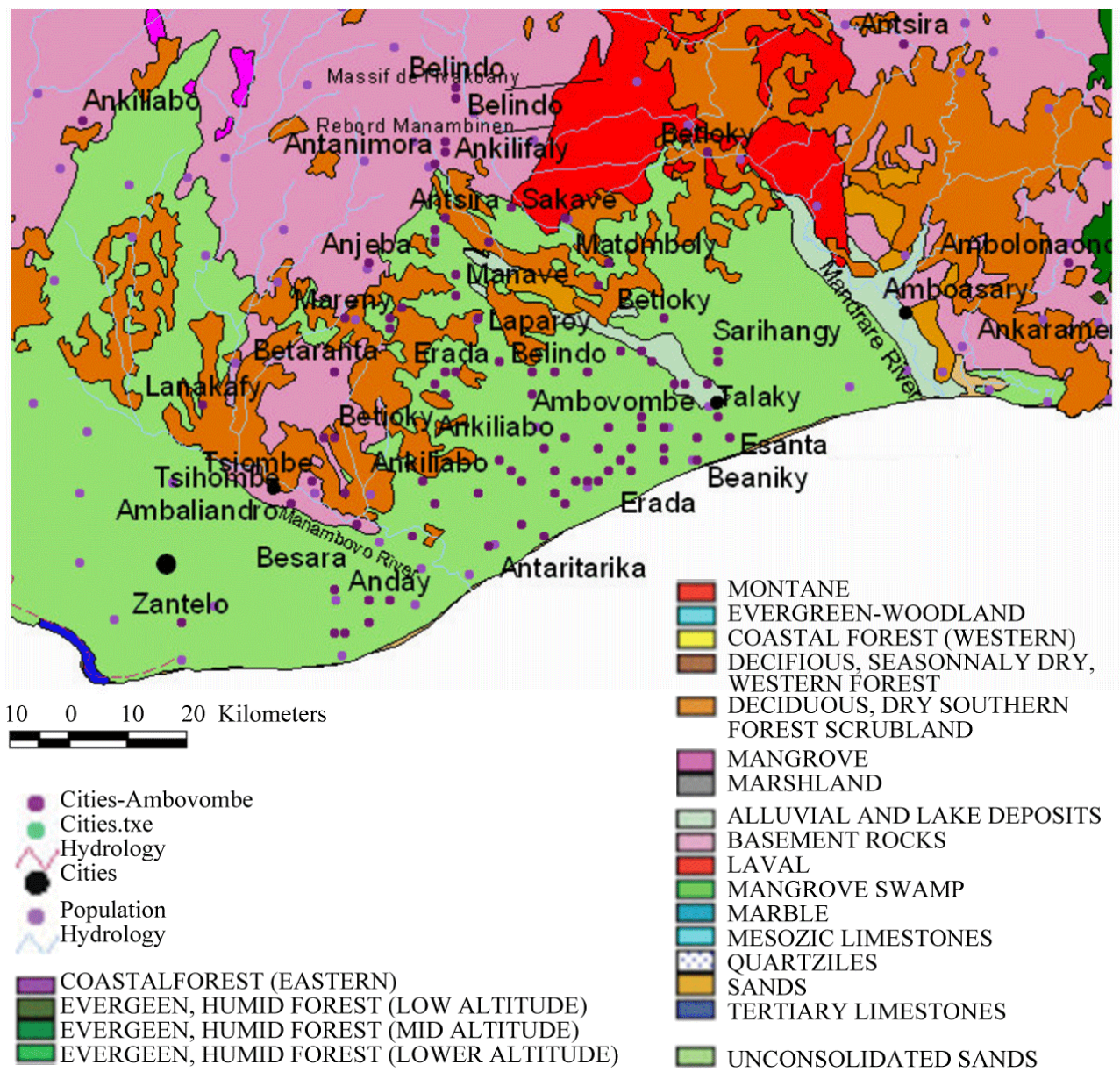

Figure 1. Ambovombe. 
income. For some comparison, the cost of drinking water in Madagascar from supply sources ranges from US\$ $0.39 / \mathrm{cm}$ to US\$ $1.30 / \mathrm{cm}$ [9]. In the United States the average cost is US $\$ 0.66 / \mathrm{cm}$. The country with the most expensive water in the OECD is Denmark at US\$ 2.24/ $\mathrm{cm}[10]$.

When considering what people are willing to pay for water Economist most commonly employ a contingent valuation model. The assumption is that an individual's demand for a good is a function of the price of the good, prices of substitute and complementary goods, the individual's income, and the individual's tastes [11]. Others, however, [12] further divide the concern of influences over willingness-to-pay for water into economic, institutional, and political and social concerns. Economic concerns are over ability to pay as much as the function of the price. Institutional concerns are commonly tied to public policy. Are there grant programs? Is there a mechanism to charge different rates based upon consumer income? Is there the ability of the state to institute taxes to the benefit of water system creation or management? Leading institutional approaches [13] concur that water access is an economic concern, an institutional concern, and a political and social concern. Saleth and Dinar [13] consider water as a public good, the nature and ability of private rights systems, water pricing policy structures, market mechanisms, and the like. They agree with Douglass North [14] that institutional performance is constrained by rent-seeking behavior of elites and politically powerful groups. However, they see increasing water scarcity, macro-economic challenges, macroeconomic adjustment policies, sociopolitical liberalization, reconstruction programs and the rising power of the middle class as all contributing to a reduction in the barriers institutions face. Economic gains, they argue, are likely to be realized from allocation-oriented institutional change are substantial and also increasing with every increase in water scarcity [13]. In Ambovombe there is no allocation-oriented institutional change so the opportunity for those economic gains to flourish are constrained [15]. What is left is whether user willingness-to-pay can drive institutional change to overcome the challenges to supply and, subsequently, the regularization of the water market.

Of note, there is an ongoing vociferous debate as to whether there should be water concerns with paying for water at all. Advocates for water as a human right often conclude that the Dublin Principles are flawed and that the commodification of water should be abandoned. The debate has become more complex to include a large variety of opinions that take into account not only a dichotomous yes-no response but conditions under which it should be free, and how might prices be structured in such a way to ensure that water is free for those that need it to be free but "real" for those that can afford it. Block pricing schemas of various sorts have come to dominate the literature [2]. Another aspect of this debate focuses on the idea that a scientific discourse on the provision of ecologically provided goods is critical but it is also necessary to understand the community's perspective. "It is only on this basis that 1) environmental policies can be implemented in modern democracies; 2) the community's justice issues can be specifically addressed; and 3) decision makers can be advised on what is a fair decision in the community's view" [16]. This study is largely inductive. The effort to obtain community perspectives necessitates an approach to this question that reflects respondent views rather than a quest to weigh in on this theoretical debate. Interview and focus group responses support the notion of paying for water as a necessity. As put by a young man on the outskirts of Ambovombe town.

Water's rare. Maybe water from Ambovombe [town] comes here sometimes. So the price is 750 [francs; about US\$ 0.08], but that is not something that you just can find anywhere. You have to try hard to access to a bucket of water because there's none anywhere. If there is a small quantity in town, everyone just comes there and buys it and then it's not sufficient for everyone... [sic] If there's something like [a regular but expensive water supply] I'm sure we would keep the money for the improvement of people's lives. Yeah, I'm positive, yeah [regular but expensive water supply] would work and that would bring change for people's lives.

Survey responses indicate that 70 percent of the Ambovombepopulation are willing not only to pay for water but to pay a higher price for water than they currently do if it ensured a regularity of supply. As a result of this strong finding this study finds the debate over whether water should be free to be moot in the Ambovombe context. There are no discussions on the horizon that will bring public or donor funds to a model of water delivery that ensures a free public good and, moreover, the public does not expect it. The relevance of the question, therefore, is the conditions under which people are willing to pay more. If we can understand what motivates a willingness-to-pay more than it may be possible to address some of the perceived social and political barriers to payment. This exercise is an effort to go beyond the misassumption that poor populations are unwilling and unable to pay for water and consider the mechanisms under which they would feel it appropriate to pay for water and how much that cost should be.

\subsection{Socio-Economic and Demographic Variables}

Socioeconomic and demographic variables are a common starting place for determining personal preference. 
There may, for instance, be a difference in water usage based upon ethnic difference, those who are more educated might have more novel coping strategies for shortage, and larger families may find themselves more constrained in their choices. The variables explored included:

Age, Sex, Marital Status (controlling for polygamy), Number of Children, Schooling, Literacy, Ethnicity, Alternate Identity (kinship group), Primary Sources of Information, Religion, Occupation, Household Size (and distribution)

This is consistent with other studies conducted in the developing worldwhich "show that willingness-to-pay varies according to household socio-economic characteristics (e.g. level of education, employment in the formal sector, income), and the characteristics of the new and existing water supplies (e.g. reliability, ease of access, quality)." [17] Yet, in the case of Ambovombe these variables prove to be far from holding robust relationships with a willingness-to-pay. (See Table 1) This is not terribly surprising as how one defines community in Ambovombe and the expectations one has for the state in providing key services in Ambovombe are not significantly influenced by any of these factors with the exception of the size of the kinship group. Of these, the variables that proved to have at least some interaction with willingness-to-pay for water included Age, Size of Kinship Group (a derived variable), Occupation, Sex, Marital Status, and Education.

\subsection{Income}

Income is, arguably, the single most common factor influencing a person's perceptions regardless of perception type. One would clearly expect that someone who has more money would be willing to pay more money to regularize their water supply and pricing. Indeed, a recent study of willingness-to-pay for water in Mexico found the most robust predictors of willingness-to-pay to ensure supply to be age, sex (women willing to pay more), and income [18]. Measuring income in a rural area comprised of agricultural and pastoral activities can at best be described as challenging. Numerous tactics have been employed by scholars. Anthropologists and practitioners of Rapid Rural Appraisal generally use a list of indicators of relative wealth (such as metal roofs, paddocks, radios, etc.). This works well when considering intra-communal class structures. For the purposes of this study, however, an agricultural economic method was employed. A portion of the survey included variables to ascertain both quantity of goods either owned or harvested and earnings from goods sold. These variables included:

- Land (ha), Rice harvest (by each season);

- Other Crops (broken down by type);

- Earnings from Crop Sales;

- Collected Items (Broken down by item);

- Livestock (broken down by type);

- Earnings from Livestock Sales (broken down by livestock type);

- Salaries;

- Other cash income.

Production and livestock variables were valued at average local market prices, standardized, weighted and then constructed into a proxy Income Index. Land was left as an independent variable. In the case of "Income" outliers were explored and, if unexplainable, removed. In the case of Land, surveyors conducted interviews in the field and noted discrepancies between their own estimates and the respondents (these were rare). Crosschecking between land size and production, comparing to average levels, served as a secondary check of response authenticity. The average income and land size, and their correlation with willingness-to-pay is reported in Table 2. Note that both figures are consistent with other studies [19].

Once again it is surprising that neither income nor land interact with a willingness-to-pay. That is, there is no tendency for someone with a higher or income or more land to be willing to pay for more money for regularized water supply than someone with a lower income or a

Table 1. Socio-economic and demographic relationships with willingness-to-pay.

\begin{tabular}{cc}
\hline Variable & Response \\
\hline Age & $33 \%$ (average respondent age) \\
Size of kinship group & $32 \%$ (belong to a large group) \\
Occupation (farmer) & $97 \%$ (self identify as a farmer) \\
Sex (male) & $58 \%$ (of sample is male) \\
Marital status & $82 \%$ (of sample is married) \\
Education (years) & $24 \%$ (have at least a basic education) \\
\hline
\end{tabular}

${ }^{*}=\mathrm{p}<0.05 ;{ }^{* *}=\mathrm{p}<0.01$. 
small amount of land. This may be explained, in part, by the extrodinarily high average willingness. 101 ariary per bucket (US\$ 3.37 per $\mathrm{cm}$ ). For the sake of comparison, the high end used in a recent study of willingness-to-pay in the United States to be $\$ 1.59 / \mathrm{cm}$ [20].

\subsection{Macro-Structures}

There is a difference between whether a person is willing to pay for water to ensure the regularity of supply and whether, more philosophically, that person thinks that water should be a free good. It would not be a reach to assume that there would be, nonetheless, a high correlation in response. Closely tied to the idea of water cost as a function of supply is who is responsible for providing it and who should be. This mandates a look at macrostructural change. A number of variables in this study were employed to probe perceptions of macro-structures and macro-structural change. These include:

- Should water be a free good;

- Whose job is it to provide water;

- How effective is the AES;

- Desire to see an increase in Malagasy companies;

- Desire to see an increase in Foreign companies;

- Public vs Private source preference;

- A series of questions about political change (democratization, leadership, etc.);

- A series of questions about the quality of governance. From this a proxy variable of "liberal" was created to hone in on political changes towards individual responsebility and market integration into domains hitherto controlled by the state. The rationale is that someone who is more liberal-minded might be more likely to expect little from the state in the provision of water and more from the market. They might also be willing to pay more for the good as part of their increasing individual role (and, perhaps, in lieu of a large, tax-supported state). Liberalism, it turns out, does not correlate with a willingnessto-pay more for water. Indeed, few political perceptions do. The factors that did bear some relationship to willingness-to-pay were a perception that water should be free, that the state should be the supplier of water, that an increase in Malagasy companies in the region would be a boon, that an increase in foreign companies in the region would be a boon, and that supplying water through private trucks (as opposed to the state mechanism, the AES) would be positive. The strength of such views and the correlation to willingness-to-pay are indicated in Table 3.

\subsection{Micro-Structures}

There is a rich and growing body of literature on the importance of the way in which we define community. In Ambovombe how one defines community is seminal to how one perceives state actions as well as the potential success of community based programs. Indeed, if "communities" are supposed to be more responsible for the delivery of water then focusing on, and supporting a unit as "the community" that is not locally accepted as "community" is a recipe for disaster. Accountability, participation, and trust will all be low. Unfortunately, it appears that "community" in Madagascar's water sector are defined at the commune level while communities themselves self define at the lower fokontanylevel or the most local level of hamlet. This has led to an erosion of virtually every state and donor-funded effort to create not only water users groups but community management of any type. There is reason to contend, therefore, that understanding the micro-level factors that influence will-

Table 2. Land and income relationships with willingness-to-pay.

\begin{tabular}{ccc}
\hline Variable & Response & Correlation w/willingness \\
\hline Land & 2.34 ha (average plot size) & 0.05 \\
Income & 294457 ariary (US\$162) Average per household per annum & -0.04 \\
\hline
\end{tabular}

Table 3. Macro-structural relationships with willingness-to-pay.

\begin{tabular}{ccc}
\hline Variable & Response & Correlation w/willingness \\
\hline Water should be free & $73 \%$ (yes) & $-0.143^{* *}$ \\
State's job & $14 \%$ & $-0.093^{*}$ \\
Pro-malagasy companies & $74 \%$ & 0.003 \\
Pro-foreign companies & $72 \%$ & -0.44 \\
Private trucks & $49 \%$ (support the idea of private trucks) & $0.21^{* *}$ \\
\hline
\end{tabular}

\footnotetext{
${ }^{*}=\mathrm{p}<0.05 ;{ }^{* *}=\mathrm{p}<0.01$.
} 
ingness-to-pay in Ambovombe are important. As such, a series of questions were explored both in survey and focus group to form the following variables:

- A series of questions aimed at defining "community";

- The role of the Hamlet and the Fokontany (the two most commonly identified levels for "community";

- The existence of a community borehole or well (whether public or private);

- The existence of a water user's group;

- The quantity of water used per day (broken down by season);

- The amount of water purchased per day (broken down by season);

- Perceived water shortage (a derived variable);

- Water availability for cattle;

- Perceived need of water for cattle;

- Sources of water;

- Time spent collecting water;

- Perception of quality of live;

- The existence of NGOs in the area;

- A series of questions about community associations and the civil society.

The importance of community self-definition mandates its inclusion in any estimation. Other factors which proved important to include are whether there is a borehole or well in the community, whether there is a perceived need for water for cows, how much water is used in the household, what the perceived water shortage is, and whether there is a functioning water users group in the community. The responses to these questions and the correlation to willingness-to-pay are found in Table 4. Notably, time costs are high and consumption is low. On average respondents said they spend 3.57 hours per day securing water for their families culminating in an average of 59 liters per household per day. When asked in an open response question about their most pressing need, 86 percent responded that water for consumption dominated their concerns. The remaining responses included water for agriculture, water for livestock, food, schools, hospitals, electricity, medicine, and a general sufferance. As importance as these factors are, they do not, with the exception of water quantity used, interact greatly with a willingness-to-pay for water to ensure supply.

\section{What Influences How Much a Person Is Willing to Pay for Water in Ambovombe?}

While this author has focused on institutional concerns in Ambovombe's water sector in other work, the study herein focuses on political and social concerns. Is there a large gap between urban and rural services? How pressing is the concern over water as compared to other basic goods or conditions? What is the perceived willingnessto-pay a higher amount and what drives that perception? The most common tool for measuring of influences on willingness-to-pay is a probit model. For instance, Olmstead's [21] dependent variable is the relationship between a user's likelihood of receipt of water service and the independent variable. She uses a probit model to estimate two model functions. Herein, however, the dependent variable is the amount of money an individual is willing to pay for water. This is a currency figure expressed in Malagasy ariary. It is therefore interval data, not bivariate. As such, the data doesn't meet the criteria for Logistical or Probabalistic Regression. Linear regression, is therefore employed. This is a common approach to considering impacts on willingness-to-pay under such data criteria [22-26]. The independent variables in this study also vary from econometric studies. What is kept as relevant from contingent valuation models are income and socio-economic and demographic variables. Added to these are perceptions of macro-structures, generally political in nature, and perceptions of micro-structures, such as definitions of "community," perceived water shortage, and the existence of functioning water-users groups.

Table 5 depicts 4 models of influences on willingness-to-pay broken down by the category types discussed above: micro perceptions, macro perceptions, income, and socio-economic and demographic variables. Model 1

Table 4. Micro-structural relationships with willingness-to-pay.

\begin{tabular}{crr}
\hline Variable & Response & Correlation w/willingness \\
\hline Hamlet/fokontany & $90 \%$ (defined hamlet or fokontany as community) & -0.08 \\
Borehole & & $73 \%$ (have an unfilled need) \\
Water for cows & 59 liters (household water use per day) \\
Water quantity used & 62 liters (perceived household water shortage per day) \\
Perceived water shortage & $6 \%$ (have a functioning group in their community) \\
Water users group & $-0.12^{* *}$
\end{tabular}

${ }^{* *}=\mathrm{p}<0.01$. 
Table 5. What drives a perceived willingness-to-pay for more for water?

\begin{tabular}{|c|c|c|c|c|c|}
\hline Category & Variable & Model 1 & Model 2 & Model 3 & Model 4 \\
\hline \multirow{6}{*}{ Micro-perceptions } & Hamlet/fokontany & $-2.82^{* *}$ & $-2.16^{* *}$ & $-2.92^{* * * *}$ & $-2.92^{* * *}$ \\
\hline & Borehole & -1.10 & -1.23 & $-2.13^{*}$ & $-2.13^{*}$ \\
\hline & Water for cows & $-2.56^{* *}$ & $-2.64^{* * *}$ & $-3.53^{* * *}$ & $-3.55^{* * * *}$ \\
\hline & Water quantity used & -0.20 & -0.59 & & \\
\hline & Perceived water shortage & 0.43 & 0.55 & & \\
\hline & Water users group & -0.28 & -0.56 & & \\
\hline \multirow[t]{5}{*}{ Macro-perceptions } & Water should be free & -0.30 & -0.30 & & \\
\hline & State’s job & $2.26^{* *}$ & $2.88^{* *}$ & $2.49^{* *}$ & $2.49^{* *}$ \\
\hline & Pro-malagasy companies & -0.41 & -0.53 & & \\
\hline & Pro-foreign companies & -1.28 & -0.90 & & \\
\hline & Private trucks & $7.25^{* * *}$ & $7.55^{* * *}$ & $8.05^{* * *}$ & $8.06^{* * *}$ \\
\hline \multirow[t]{5}{*}{ Income } & Income & -0.24 & -0.03 & 0.10 & \\
\hline & Land & 1.40 & 1.42 & & \\
\hline & Age & 1.40 & 1.15 & & \\
\hline & Size of kinship group & -1.07 & & & \\
\hline & Occupation (farmer) & -0.557 & & & \\
\hline \multirow{5}{*}{ Socio-economic } & Sex (male) & 0.11 & & & \\
\hline & Marital status & 1.52 & & & \\
\hline & Education (years) & -0.39 & & & \\
\hline & Adj R-sq & 0.30 & 0.27 & 0.27 & 0.27 \\
\hline & $\mathrm{F}$ & $7.68^{* * * *}$ & $9.88^{* * *}$ & $25.18^{* * * *}$ & $30.30^{* * *}$ \\
\hline
\end{tabular}

${ }^{*}=\mathrm{p}<0.05 ;{ }^{* *}=\mathrm{p}<0.01 ;{ }^{* * *}=\mathrm{p}<0.001$.

includes the most robust variables from each of these categories. Given the correlation findings discussed above in the socio-economic and demographic category section we would not expect these factors to play much of a role influencing individual willingness-to-pay and, indeed, such variables only serve to detract from the model. Model 2 runs the same data but excluding the socioeconomic and demographic variables. This serves to increase the strength of the model by an F value of more than two points. Model 3 takes the next step of considering the least influential variables in the other three categories. There is little to expect from the income index proxy given the correlations above. However, because it is so counter-intuitive that income would not influence willingness-to-pay Model 3 leaves income in the model. This leaves room for comparison to the identical model but with income removed (Model 4). We find that removing does nothing to reduce the amount of the response the model describes (Adj R-sq $=0.27$ ) while significantly increasing the power of the model (to $F=30.30$, $\mathrm{p}<0.000$ ). Clearly, however counter-intuitive, income just isn't a factor in whether a person is willing to pay more for water.

The factors that are powerful in describing a perceived willingness-to-pay for water if it ensures supply tend to come from micro-perceptions. Someone that perceives the Hamlet or Fokontany, as opposed to the commune, as his or her community is willing to pay less for water. This coincides logically with the macro-perception that it is the state's job to provide water (which significantly influences a willingness-to-pay). There is an important policy point here. People are willing to pay more if the provision is made at a higher level. Where at present community is being defined by the state and donors as the commune level, those who share that identification are willing to pay more than those who think the institutions created for local delivery are misplaced and/or lack accountability. If the service of water is moved up to the state level then people are willing to pay more. The presumption, focus groups make clear, is that there just isn't 
water supply in Ambovombe. State provision for water will somehow have to include a pipeline or other engineering response. Their perception is well-founded. A recent in-depth JICA study concludes that the hydrologically closed basin offers no options for community enterprise or groundwater resources to answer to water call. It proposes an inter-regional pipeline.

The other influential factors on willingness-to-pay are equally intuitive. If a person is fortunate to live in one of the minority communities that has a borehole or well it stands to reason that that person will be less likely to want to pay more for water to regularize supply. Supply in these communities (26\%) are already more regular. Livestock, and particularly the livestock of choice in the region, cows, propose a dramatic challenge for water supply. There are alternatives. Most notably, cactus fruit (raketa) are eaten by cattle. However, environmental factors and population increases have led to a decline in the cacti that produce raketa [27]. It is more likely today that raketawill be found in neighboring Tsihombe than in Ambovombe. With decreasing raketathere is an increasing need for water for cattle. Where cattle need to drink water consumption per household goes up dramatically. It stands to reason that the higher consumption drives an unwillingness to pay more per unit. Of course, as championed in the 2006 Human Development Report which focuses on water, there is an important management distinction to be made between prowduction water and household water. However, that distinction remains theoretical in Ambovombe. Water sources are the same regardless of the water need and cattle are integral to sustaining human livelihoods regardless of whether that person considers him or herself a farmer or herder. More cattle in Androy is considered a sign of wealth $[8,28]$. More water need for that cattle means more water consumption and less willingness-to-pay a higher unit cost.

If there is one surprising finding in this study it is the strength of the role of private trucks. While everyone in Ambovombe district dreams of and talks incessantly about the day a pipe will be built, today's realities are that water coming from outside Androy comes by truck. When asked "who would you rather buy water from" (and presented with public and private options) the answer is overwhelmingly “it doesn't matter”. But, when asked "Do you think it would be an improvement if private trucks sold water instead of the AES even if the cost was higher?" a shocking 49 percent say "yes". While the state should be providing water the population is perceptive enough to note that it isn't and isn't likely to. Therefore, despite a desire for state action, nearly half would pay more to see greater market intervention. Those who are willing to pay more for private water are willing to pay more period.

\section{Conclusions}

Is there a market answer for Ambovombe's water woes? The answer would seem to be "yes, but". The "yes" is practical. People are willing to pay tremendous amounts for water. US\$ 3.37/cm is significantly higher than average cost of water within Madagascar's (few) water districts. It is five times the average price for water in the United States and a third again above the most expensive water in any OECD country (not controlling for purchasing power). The factors that influence that willingness are decidedly private in nature. People don't care where the water comes from as long as it comes. Given the current system about half the population wants to see the rise of private water trucks - an astoundingly high percentage in a region where the state has always been the provider and the only experience with the private sector is predatory marketeers (in water, cattle sales, etc.). The state-run AES enjoys little popular faith and is perceived as inefficient, corrupt, and short on answers. That said, there is still a desire for state action.

Ambovombe-Androy does not have sufficient water resources to slake its populations' thirst. Fortunately, there are two major river basins, both within semi-humid regions, within $100 \mathrm{~km}$. Ultimately either the population is going to have to move to the water or the water is going to have to be moved to the population. Given land tenure challenges there appears little choice but to embark on an inter-regional water scheme. Communities are ill-placed to organize across boundaries and fund large scale development projects. They are certainly financially incapable of paying for capital costs. There will have to be macro-level intervention. Yet communities in Ambovombe-Androy would be willing to pay user-fees that would over time cover not only the resource but the infrastructure investments. Indeed, with higher level intervention that ensures resource delivery there is a willingness-to-pay more. Moreover, it appears that while the community holds a preference for state action it would accept private action if it ultimately delivered the resource. What communities appear unwilling to accept are micro level answers to macro level problems. They are willing to pay less to community level water managers, part out of lack of faith in community mechanisms and part out of a savvy understanding that community level answers will not ensure a regular supply. There is one caveat: where there is regular supply people want to pay less. Once a regular supply is established there is thus reason to believe willingness-to-pay will decrease. From the perspective of state water policy, and donor financing, that is a reason for concern. For the perspective of private investment it is also a concern that it will be increasingly difficult to charge rates that will ensure the investment is repaid. Then again, regularization of supply drives down 
costs [29]. That is why water is so cheap in OECD countries even though so much of flows through the taps. Perhaps that, and not a debate over public versus private delivery, is all that Ambovombe-Androy residents are looking for.

\section{Acknowledgements}

The author wishes to thank California State University, Long Beach and the US Southeast Climate Consortium, supported by US NOAA and USDA, for ongoing support which facilitates this research.

\section{REFERENCES}

[1] World Bank/PAEPAR, "Projet Pilote d'alimentation en eau Potable et Assainissement en Milieu Rural,” Mission de Suivi du 30 avril au 17 mai 2003. Rapport de Mission de Annie Savina, 2003.

[2] P. H. Gleick, "Global Freshwater Resources: Soft-Path Solutions for the 21st Century," Science, Vol. 302, No. 5650, 2003, pp. 1524-1258. doi:10.1126/science.1089967

[3] K. H. Redford and J. A. Mansour, "Traditional Peoples and Biodiversity Conservation in Large Tropical Landscapes,” The Nature Conservancy, Arlington, 1996.

[4] J. Fisher, "The History of Landholding in England," Transactions of the Royal Historical Society, Vol. 4, No. 12, 1876, pp. 97-187. doi:10.2307/3677922

[5] V. Ostrom, "The Political Economy of Water Development," The American Economic Review, Vol. 52, No. 2, 1982, pp. 450-458.

[6] International Institute for Sustainable Development, "Ministerial Declaration, Fourth World Water Forum, Local Actions for a Global Challenge,” 2006.

http://www.iisd.ca/ymb/worldwater4/

[7] ICWE, "The Dublin Statement on Water and Sustainable Development," International Conference on Water and the Environment, Dublin, 26-31 January 1992.

[8] R. Marcus, "Where Community Based Water Resource Management Has Gone to Far: Poverty and Disempowerment in Southern Madagascar," Conservation and Society, Vol. 5, No. 2, 2007, pp. 202-231.

[9] A. Dinar and A. Subramanian, "Water Pricing Experience: An International Perspective,” Technical Paper No. 386, World Bank, Washington DC, 1997.

[10] NUS Consulting Group, "2005-2006 International Water Report \& Cost Survey,” A Business of National Utility Service, Inc., Park Ridge, 2006.

[11] D. Whittington, J. Briscoe, X. Mu and W. Barron, "Estimating the Willingness to Pay for Water Services in Developing Countries: A Case Study of the Use of Contingent Valuation Surveys in Southern Haiti," Economic Development and Cultural Change, Vol. 38, No. 2. 1990, pp. 293-311. doi:10.1086/451794

[12] S. M. Olmstead, "Thirsty Colonias: Rate Regulation and the Provision of Water Service,” Land Economics, Vol.
80, No. 1, 2004, pp. 136-150. doi:10.2307/3147149

[13] S. R. Maria and A. Dinar, "The Institutional Economics of Water: A Cross-Country Analysis of Institutions and Performance,” The Edward Elgar/World Bank, Cheltenham and Northampton, 2004.

[14] D. C. North, "Institutions, Institutional Change, and Economic Performance,” Cambridge University Press, Cambridge, 1990. doi:10.1017/CBO9780511808678

[15] R. Marcus and J. O. Marcus, "Exit the State: Decentralization and the Need for Local Social, Political, and Economic Consideration in Water Resource Allocation in Madagascar and Kenya," Journal of Human Development. Vol. 9, No. 1, 2008, pp. 23-45. doi:10.1080/14649880701811385

[16] G. J. Syme, E. Kals, B. E. Nancarrow and L. Montada, "Ecological Risks and Community Perceptions of Fairness and Justice: A Cross-Cultural Model,” Risk Analysis, Vol. 20, No. 6, 2000, pp. 905-916.c

[17] A. Gadgil, "Drinking Water in Developing Countries," Annual Review of Energy and the Environment, Vol. 23, No. 1, 1998, pp. 253-286. doi:10.1146/annurev.energy.23.1.253

[18] G. S. M. de Oca, I. J. Bateman, R. Tinch and P. G. Moffatt, "Assessing the Willingness to Pay for Maintained and Improved Water Supplies in Mexico City," CSERGE Working Paper ECM 03-11, 2003.

[19] Government of Madagascar, "Enquête Périodique Auprès de Ménages 2005: Rapport Principal,” Ministere de l'Economie, des Finances, et du Budget, Antananarivo: Repoblikan'iMadagasikara, 2006.

[20] R. G. Alcubilla and R. Garcia, "Derived Willingness-toPay for Water: Effects of Probabilistic Rationing and Price,” Unpublished, 2005.

[21] S. M. Olmstead, "Thirsty Colonias: Rate Regulation and the Provision of Water Service," Land Economics, Vol. 80, No. 1, 2004, pp. 136-150. doi:10.2307/3147149

[22] M. H. Chan, E. Baruwa, D. Gilbert, K. Frick and N. Congdon, "Willingness to Pay for Cataract Surgery in Rural Southern China,” Ophthalmology, Vol. 114, No. 3, pp. 411-416, 2006.

[23] C. A. Marra, L. Frighetto, A. F. Goodfellow, A. O. Wai, M. L. Chase, R. E. Nicol, C. A. Leong, S. Tomlinson, B. M. Ferreira and P. J. Jewesson, "Willingness to Pay to Assess Patient Preferences for Therapy in a Canadian Setting," BMC Health Services Research, Vol. 5, No. 1, 2005, p. 43.;

[24] N. B. Leigh, S. Tsao, D. L. Zawisza, M. Nematollahi and F. A. Shepherd, "A Willingness-to-Pay Study of Oral Epidermal Growth Factor Tyrosine Kinase Inhibitors in Advanced Non-Small Cell Lung Cancer,” Lung Cancer, Vol. 51, No. 1, 2005, pp. 115-121.

[25] D. Whittington, J. Briscoe, X. Mu, W. Barron, "Estimating the Willingness to Pay for Water Services in Developing Countries: A Case Study of the Use of Contingent Valuation Surveys in Southern Haiti," Economic Development and Cultural Change, Vol. 38, No. 2, 1990, pp. 293-311. 
[26] E. L. Michalson, "Recreational and Sociological Characteristics of Hunters and an Estimate of the Demand for Hunting in the Sawtooth Area of Idaho,” Water Resources Research Institute, University of Idaho, Moscow, 1973.

[27] J. C. Kaufmann, "La Question des Raketa: Colonial Struggles in Madagascar with Prickly Pear Cactus, 1900-1923,” Ethnohistory, Vol. 48, No. 1-2, 2001, pp. 87-121. doi:10.1215/00141801-48-1-2-87
[28] J.-A. Rakotoarisoa, “Mille Ansd'Occupationhumainedans le Sud-Est de Madagascar: Anosy, Uneile au Milieu Desterres,” L’Harmattan, Paris, 1998.

[29] R. Bhatia and M. Falkenmark, "Water Resource Policies and the Urban Poor: Innovative Approaches and Policy Imperatives," Water and Sanitation Current, UNDPWorld Bank Water and Sanitation Program, Washington DC, 1993. 